University of San Diego

Digital USD

Spring 5-18-2021

\title{
Was Trump's deployment of federal officers to Portland, Oregon and other cities during the summer of 2020 legal and constitutional?
}

Celina Tebor

University of San Diego

Follow this and additional works at: https://digital.sandiego.edu/honors_theses

Part of the American Politics Commons

\section{Digital USD Citation}

Tebor, Celina, "Was Trump's deployment of federal officers to Portland, Oregon and other cities during the summer of 2020 legal and constitutional?" (2021). Undergraduate Honors Theses. 83.

https://digital.sandiego.edu/honors_theses/83

This Undergraduate Honors Thesis is brought to you for free and open access by the Theses and Dissertations at Digital USD. It has been accepted for inclusion in Undergraduate Honors Theses by an authorized administrator of Digital USD. For more information, please contact digital@sandiego.edu. 


\section{Honors Thesis Approval Page}

Student Name: Celina Tebor

Title of Thesis: Was Trump's deployment of federal officers to Portland, Oregon and other cities during the summer of 2020 legal and constitutional?

Accepted by the Honors Program and faculty of the Department of Political Science, University of San Diego, in partial fulfillment of the requirements for the Degree of Bachelor of Arts.

\section{FACULTY APPROVAL}

Del Dickson

Del Dickson

$\frac{5 / 14 / 21}{\text { Date }}$ 
Was Trump's deployment of federal officers to Portland, Oregon and other cities during the summer of 2020 legal and constitutional?

\author{
A Thesis \\ Presented to \\ The Faculty and the Honors Program \\ Of the University of San Diego
}

\author{
By \\ Celina Buenafe Tebor \\ Political Science \& Communication Studies
}

2021 
Tebor 1

\section{INTRODUCTION}

Amidst nationwide protests calling for racial justice after the killing of George Floyd over the summer of 2020, President Donald Trump deployed federal troops to several cities across the country, including Portland, Oregon. The legal basis for sending the troops was to protect federal property, and relied upon the powers of the Department of Homeland Security and an executive order from the summer. However, President Trump's rhetoric surrounding the deployment suggested that they were truly sent into cities to serve as domestic law enforcement and quell the protests. And as the troops' presence lengthened and increased in Portland, reports of kidnapping and tossing protestors into unmarked vans and targeting journalists and legal observers with munitions began to surface while officials and experts questioned the legality of Trump's actions.

Ultimately, President Donald Trump legally deployed federal troops to the city of Portland during summer 2020. However, once they arrived in the city, they began to engage in illegal and unconstitutional behavior that plainly violated the 10th Amendment and the basic American principle of federalism, as well as the 1st and 4th Amendment rights of protesters, journalists and legal observers. Local, state, and national leadership denounced the presence of the federal troops in Portland, and multiple lawsuits have been filed in response, some of which are still pending.

This analysis will delve into the background of the protests and deployment of federal troops and discuss the legal issues at hand in determining the legality and constitutionality of President Trump's actions. It will include reactions from political leaders, as well as several lawsuits that have claimed violations of 1st, 4th, 5th, and 10th Amendment rights of Portlanders. Finally, it will end with a legal analysis and conclusion of whether Trump's act of deploying federal officers to Portland was legal. 
Tebor 2

\section{BACKGROUND AND HISTORY OF PORTLAND PROTESTS}

George Floyd was a 46-year-old Black man who died at the hands of police in Minneapolis, Minnesota on May 25, 2020. The officer who killed Floyd held his knee against Floyd's neck for over eight minutes as Floyd repeatedly pleaded "I can't breathe," video evidence shows. ${ }^{1}$ Floyd's death sparked nationwide protests calling for justice and an end to police brutality against Black Americans. These protests came alongside the larger Black Lives Matter movement which has existed for years prior to Floyd's death.

Many dispute the exact timeline of when protests over Floyd's death began in Portland, but the general consensus is that they began over Labor Day weekend in 2020. Thousands came out to the streets to protest in the days following Floyd's death. Many protestors were peaceful. Some were not. While Portland Mayor Ted Wheeler, who serves as police commissioner of the city, was criticized for law enforcement's response to the protests, often deploying tear gas and less-lethal munitions, President Donald Trump believed Wheeler was not doing enough to quell protests. ${ }^{2}$ Trump had previously used federal forces to disperse a protest in front of the White House in Washington, D.C. in June 2020. ${ }^{3}$ And similarly to Portland, Trump deployed federal troops to Chicago and said he had plans to send more to New York, Philadelphia, Detroit and other urban centers in July. ${ }^{4}$

After protests stretched for over a month straight on a nightly basis, Trump signed an executive order on June 26, 2020 allowing for the deployment of Department of Homeland Security officers in order to protect federal property in cities across the nation, including

\footnotetext{
${ }^{1}$ The New York Times, What We Know About the Death of George Floyd in Minneapolis, The New York Times, October 23, 2020.

${ }^{2}$ Associated Press, Portland mayor demands Trump remove federal agents from city, The Guardian, July 19, 2020.

${ }^{3}$ Buchanan v. Trump, 1:20-cv-01542 ( D.D.C. 2020).

${ }^{4}$ Peter Baker, Zolan Kanno-Youngs and Monica Davey, Trump Threatens to Send Federal Law Enforcement Forces to More Cities, The New York Times, July 24, 2020.
} 
Tebor 3

Portland. In Portland, the property in question was the Mark O. Hatfield Federal Courthouse, which was routinely covered with graffiti: common marks included phrases such as "BLM," for "Black Lives Matter," or “ACAB,” standing for "All Cops Are Bastards.” The courthouse is located in Downtown Portland, the site of many protests and clashes between protesters and law enforcement. A leaked Department of Homeland Security memo also noted the Edith Green Wendell Wyatt Federal Building, a U.S. Immigration and Customs Enforcement Building, Pioneer Courthouse, and Gus J. Solomon Courthouse as "federal facilities that have been targeted during the recent civil unrest in Portland, Oregon." The memo says the Mark O. Hatfield Federal Courthouse has been "the epicenter for targeted vandalism since early June 2020."5

Trump deployed federal troops from the Department of Homeland Security to Portland ahead of the Fourth of July weekend. ${ }^{6}$ Agents from the Department of Homeland Security included troops from Bortac, a border patrol tactical unit similar to a SWAT team. Bortac agents are typically deployed for raids gangs that smuggle immigrants or drugs across the U.S.-Mexico border. ${ }^{7}$ The same leaked memo from the Department of Homeland Security that described the federal property in need of protection in Portland noted that "the highly skilled tactical teams assigned to support the civil unrest and riots do not specifically have training in riot control or mass demonstrations." $" 8$

Although the purpose behind the deployment of federal troops to Portland was to protect federal property, President Trump's rhetoric did not echo that sentiment. In a Tweet from July 30, 2020, Trump wrote “Kate Brown, Governor of Oregon, isn’t doing her job. She must clear out,

\footnotetext{
${ }^{5}$ Briefing memorandum from the U.S. Department of Homeland Security to the acting secretary/senior official performing the duties of deputy secretary (July 16, 2020) (on file with The New York Times).

${ }^{6}$ Jonathan Levinson, Conrad Wilson, and Ryan Hass, 50 days of protest in Portland. A violent police response. This is how we got here, Oregon Public Broadcasting, July 29, 2020.

${ }^{7}$ Ed Pilkington, 'These are his people': inside the elite border patrol unit Trump sent to Portland, The Guardian, July 27, 2020.

${ }^{8}$ The New York Times, supra note 5.
} 
Tebor 4

and in some cases arrest, the Anarchists \& Agitators in Portland. If she can't do it, the Federal Government will do it for her. We will not be leaving until there is safety!"9 This suggests that Trump deployed federal officers not only to protect federal property, but to clear out and arrest protestors who are behaving criminally or violently.

\section{THE LEGAL ISSUES IN QUESTION}

\section{A. The 10th Amendment and State Police Powers}

There is no general federal police power. The power of policing is left to the states through the 10th Amendment of the U.S. Constitution, which reads "The powers not delegated to the United States by the Constitution, nor prohibited by it to the States, are reserved to the States respectively, or to the people."10 This amendment is based on a very simple, yet important principle of the United States: federalism.

There are several reasons why the federal government owes the states respect and comity, especially where the states have traditionally exercised authority in areas such as policing. The United States is a large, diverse country, both in land mass and residents. There are unique economies, communities, and regional differences across the country, and it is up to the states and municipalities to adjust and adapt to local diversity. Greenspan argues that "people do not develop loyalty to a monolithic government and do not respect the law when they see no local connection." 11 Because state and local governments develop a stronger bond with their constituents, they are also more accountable for those constituents. "The Framers of the Constitution intended to create an indivisible Union, composed of indestructible states, by balancing the strengths of state governance with the need for federal regulation of some

\footnotetext{
${ }_{9}^{9}$ Donald Trump (@realDonaldTrump),TWITTER (Jul. 30, 2020,6:20 AM), https://twitter.com/realDonaldTrump/status/1288826742539464707.

${ }^{10}$ U.S. Const. amend. X.

${ }^{11}$ Alan N. Greenspan *, NOTE: The Constitutional Exercise of the Federal Police Power: A Functional approach to Federalism., 41 Vand. L. Rev. 1019, (OCTOBER, 1988).
} 
Tebor 5

activities," Greenspan writes. "When Congress displaces local authority, individuals lose the benefits of being governed by the states." ${ }^{\prime 2}$

William Barr, current U.S. Attorney General, boasted in 1989 about his strategy to quell looting and rioting in the U.S. Virgin Islands after Hurricane Hugo ${ }^{13}$ This interview displays Barr's history in deploying federal forces to settle unrest, and shows he has the legal knowhow to do so without declaring martial law:

Barr: "What the hell do we do? We started quickly looking at the legal books. What authority do we have to go in there and start enforcing the law in St. Croix? We looked at some statutes, and we finally decided that without Presidential authority we could send down law enforcement people to defend the federal function. That is, we said, 'People are interfering with the operation of our courts' and so on. I said, 'We can send people down to defend the federal function, keep our courts open, and if they see any crime being committed in front of them, then, as law enforcement officers, they can make the arrest.' Our object was just to get federal law enforcement down there and play it by ear. Technically, we couldn't send them down to-

Meador: Did you consider interference with the mail as a basis?

Barr: Yes, we had a whole list of things like that, interference with the mail, interference with the courts. But basically we were claiming that there was breakdown, civil unrest that was interfering with the federal function. We found these old cases that said the federal government could go in there. This was without declaring martial law."14

\footnotetext{
${ }^{12} I d$.

${ }^{13}$ Interview by James S. Young with William P. Barr, Attorney General, United States, in Charlottesville, Va. (Apr. 5, 2001).

${ }^{14} I d$.
} 
Tebor 6

This interview with Barr shows his clear understanding of the lack of a federal police power, and his willingness to find legal loopholes to create one.

One of the only functions of federal policing is to protect national resources. Wickard $v$. Filburn allowed the national government to regulate the wheat market at a time of economic depression. ${ }^{15}$ Trump's reasoning for deploying federal troops is similar: to protect federal property. Although the wheat market is clearly distinct from a federal building, the purpose of protecting national resources and property is the same.

\section{B. The Department of Homeland Security}

\section{Provision of Homeland Security Act of 2002}

Trump's deployed troops in Portland were employees of the Department of Homeland Security. He depended upon a provision of the Homeland Security Act of 2002, and his executive order which reflects similar language to the statute, to justify his deployment of federal troops to the city.

40 U.S. Code $§ 1315$, Law enforcement authority of Secretary of Homeland Security for protection of public property, generally states that the Secretary of Homeland Security shall protect any buildings, grounds, or property that are owned, occupied, or secured by the federal government and the people on that property. ${ }^{16}$ This is allowed "to the extent provided for by transfers made pursuant to the Homeland Security Act of 2002."17

Under this provision, federal agents who are deployed in connection to protect federal property may do so in the areas outside the property. Officers or agents may also make arrests without a warrant "if the officer or agent has reasonable grounds to believe that the person to be

\footnotetext{
${ }^{15}$ Wickard v. Filburn, 317 U.S. 111 (1942).

${ }^{16} \S 1315$. Law enforcement authority of Secretary of Homeland Security for protection of public property, 40 USCS $\S 1315$ (Current through Public Law 116-158, approved August 14, 2020.).

${ }^{17} I d$.
} 
Tebor 7

arrested has committed or is committing a felony," and conduct investigations — on and off the property in question. ${ }^{18}$

Beth Nakamura, a photojournalist with The Oregonian, covered protests in Portland weekly over the summer of 2020. She said she has covered protests as long as she can remember, and has been working for newspapers since 1986. From her personal experience, she saw federal agents in other areas of Downtown Portland besides surrounding the Mark O. Hatfield Federal Courthouse. ${ }^{19}$ Although the provision of the Homeland Security Act does not require federal agents to stay on federal property, their appearances in places other than the federal property that they are there to protect should be highlighted and examined, as all their actions should be directed toward guarding that federal property. Restrictions based on the opinion of Western States Center, Inc. v. United States Department of Homeland Security, discussed in Section V, prevent federal agents from controlling protest crowds beyond one block in each direction around the courthouse in downtown Portland.

"They ventured past the courthouse," Nakamura said. "And that was sort of a point of contention when it happened, but it definitely happened." 20

\section{Executive order}

On June 26, 2020 President Donald Trump signed Executive Order 13933: Protecting American Monuments, Memorials, and Statues and Combating Recent Criminal Violence. ${ }^{21}$ Similarly to the provision of the Homeland Security Act of 2002, the executive order allows the Department of Homeland Security to deploy its personnel to assist with the protection of federal monuments, memorials, statues, or property. It argues that local and federal authorities have not

\footnotetext{
${ }^{18} I d$.

${ }^{19}$ Telephone Interview with Beth Nakamura, Photojournalist, The Oregonian (Oct. 12, 2020).

${ }^{20} I d$.

${ }^{21}$ Exec. Order No. 13,933, 85 Fed. Reg. 40,081, (July 2, 2020).
} 
Tebor 8

done enough to prevent unlawful activity: "In the midst of these attacks, many State and local governments appear to have lost the ability to distinguish between the lawful exercise of rights to free speech and assembly and unvarnished vandalism. They have surrendered to mob rule, imperiling community safety, allowing for the wholesale violation of our laws, and privileging the violent impulses of the mob over the rights of law-abiding citizens." 22

Section 5 of the executive order allows DHS to deploy troops to protect federal property: "Upon the request of the Secretary of the Interior, the Secretary of Homeland Security, or the Administrator of General Services, the Secretary of Defense, the Attorney General, and the Secretary of Homeland Security shall provide, as appropriate and consistent with applicable law."23

The executive order does not explicitly say the federal government needs the support or request of local or state officials to deploy troops. However, Section 3(b) says that the Attorney General "shall, as appropriate and consistent with applicable law, work with State and local law enforcement authorities and Federal agencies to ensure the Federal Government appropriately provides information and assistance to State and local law enforcement authorities in connection with their investigations or prosecutions for the desecration of monuments, memorials, and statues, regardless of whether such structures are situated on Federal property." 24 This suggests that federal, state, and local officials should work in conjunction if Department of Homeland Security agents are deployed: both Portland Mayor Ted Wheeler and Oregon Governor Kate Brown denounced federal troops' presence in Portland. ${ }^{25}$

\footnotetext{
${ }^{22} I d$.

${ }^{23} I d$.

${ }^{24}$ Exec. Order No. 13,933, 85 Fed. Reg. 40,081, (July 2, 2020).

${ }^{25}$ Sergio Olmos, Mike Baker and Zolan Kanno-Youngs, Federal Agents Unleash Militarized Crackdown on Portland, The New York Times, July 17, 2020.
} 
Tebor 9

Executive Order 13933 was one of 69 executive orders that Trump passed in 2020; the highest number of executive orders passed by a president over the course of a year in over 25 years. ${ }^{26}$ Trump's presidency comes against the backdrop of increasing executive power in the United States in recent years: "If the New Deal-APA Era was marked by judicial deference to congressional judgments and the Environmental Era was marked by a more vigorous form of judicial activism, the deregulatory era seems increasingly to be marked by judicial deference to the executive." ${ }^{27}$ Aman argues that trends show executive power has been increasing over time in the administrative process, and that "this is very much of a piece with the general trend of increased Presidential power." ${ }^{28}$ With this context in mind, Trump's actions toward protestors over the summer of 2020 can be considered not as a unique, singular event, but part of a larger trend toward increasing executive power and overreach.

$\underline{\text { 3. Protecting American Communities Task Force (PACT), Operation Diligent Valor, and }}$

\section{$\underline{\text { Operation Legend }}$}

Over the summer of 2020, the federal government created several new task forces related to federal forces being used as a police power. At least one task force was directly in reaction to Trump's executive order.

On July 1, 2020, the Acting Secretary of Homeland Security, Chad F. Wolf, announced the Department of Homeland Security Protecting American Communities Task Force (PACT). A press release says it is "a special task force to coordinate Departmental law enforcement agency assets in protecting our nation's historic monuments, memorials, statues, and federal facilities." ${ }^{29}$

\footnotetext{
${ }^{26}$ Executive Order Disposition Tables, 60-86 Fed. Reg. 309-17895 (Jan. 3, 1995 - Apr. 4, 2021).

${ }^{27}$ Alfred C. Aman Jr., ADMINISTRATIVE LAW IN A GLOBAL ERA: PROGRESS, DEREGULATORY CHANGE, AND THE RISE OF THE ADMINISTRATIVE PRESIDENCY., 73 Cornell L. Rev. 1101, (SEPTEMBER, 1988).

${ }^{28} I d$.

${ }^{29}$ Press Release, U.S. Department of Homeland Security, DHS Announces New Task Force to Protect American Monuments, Memorials, and Statutes (July 1, 2020), https:/www.dhs.gov/news/2020/07/01/dhs-announces-new-task-force-protect-american-monuments-memorials-andstatues.
} 
Tebor 10

DHS created the PACT in direct response to President Trump's Protecting American

Monuments, Memorials, and Statues and Combating Recent Criminal Violence executive order.

Attorney General William Barr announced the launch of Operation Legend only seven days after PACT, on July 8, 2020. ${ }^{30}$ According to the Department of Justice, the operation is “a sustained, systematic and coordinated law enforcement initiative across all federal law enforcement agencies working in conjunction with state and local law enforcement officials to fight the sudden surge of violent crime," and "was created as a result of President Trump's promise to assist America's cities that are plagued by recent violence." ${ }^{31}$ On July 22, Barr noted that Operation Legend's purpose was to fight violent crime in cities: "This is a different kind of operation, obviously, than the tactical teams we use to defend against riots and mob violence," he said. ${ }^{32}$ Trump further emphasized the distinction between Operation Legend and the federal government's intervention in Portland. Although they are distinct from one another, Operation Legend again speaks to the federal government's reach into policing powers; powers they are not afforded by the U.S. Constitution.

The same day Barr and Trump remarked on Operation Legend, Reuters broke the news that the Department of Homeland Security deployed 100 federal agents to Portland on a mission named "Operation Diligent Valor," according to court documents. "The operation has involved the Department of Homeland Security’s Rapid Deployment Force. It stepped up its response to 'increasingly violent attacks' in the Oregon city on July 4, the day after a group of people broke into the courthouse, according to the affidavit by the Federal Protective Services (FPS) regional

\footnotetext{
${ }^{30}$ Press Release, U.S. Department of Justice, Attorney General William P. Barr Announces Launch of Operation Legend, (July 8, 2020), https:/www.justice.gov/opa/pr/attorney-general-william-p-barr-announces-launch-operation-legend.

${ }^{31} I d$.

${ }^{32}$ President Donald Trump and Attorney General William Barr, Remarks by President Trump on Operation LeGend: Combatting Violence Crime in American Cities (July 22, 2020)

(https://www.whitehouse.gov/briefings-statements/remarks-president-trump-operation-legend-combatting-violent-cri me-american-cities/).
} 
Tebor 11

director, Gabriel Russell," Reuters reported. ${ }^{33}$ It is not clear whether Operation Diligent Valor is connected to, or an extension of PACT.

\section{The resignation of Chad Wolf}

Acting Secretary of Homeland Security Chad F. Wolf resigned from his position on Jan. 11, 2021, following a violent insurrection at the U.S. Capitol on Jan. 6 by Trump supporters who believed the election had been unfairly stolen. In a letter to his Department of Homeland Security colleagues, Wolf said his stepping down "is warranted by recent events, including the ongoing and meritless court rulings regarding the validity of my authority as Acting Secretary." 34

The "meritless court rulings" Wolf wrote of in his letter refer to a November 2020 ruling by a New York City federal judge, saying that Wolf was not legally serving in his position and declared a memo he issued invalid that prevented new applicants to the Deferred Action for Childhood Arrivals program. ${ }^{35}$ Judge Nicholas Garaufis of the U.S. District Court of the Eastern District of New York said Wolf was serving illegally in his position due to an invalid order of succession to become Acting Secretary of the Department of Homeland Security, and therefore, the decisions he made in his position have no legal weight.

A report published by the U.S. Government Accountability Office from August 14, further details the invalid order of succession in the Department of Homeland Security. The report stated that he was illegally serving in his position after former Secretary Kirstjen Nielsen stepped down and established a new order of succession for her office. ${ }^{36}$ Following her resignation, "the incorrect individual assumed the position of Acting Secretary," the incorrect

\footnotetext{
${ }^{33}$ Gabriella Borter, Court documents reveal secretive federal unit deployed for 'Operation Diligent Valor' in Oregon, Reuters, July 22, 2020.

${ }^{34}$ Shawna Mizelle, READ: Acting Homeland Security Secretary Chad Wolf's resignation letter, CNN, Jan. 11, 2021.

${ }^{35}$ Martín Jonathan Batalla Vidal v. Chad Wolf, 1:16-cv-04756-NGG-VMS, (D. NY. 2020).

${ }^{36}$ U.S. Government Accountability Office, B-331650, Legality of Service of Acting Secretary of Homeland Security and Service of Senior Official Performing the Duties of Deputy Secretary of Homeland Security, Aug. 14, 2020.
} 
Tebor 12

individual being Kevin McAleenan, the report says. McAleenan later designated the order of succession for Acting Secretary, known as the November Delegation, which allowed Chad Wolf to become Acting Secretary following McAleenan's resignation. However, McAleenan "was not the proper Acting Secretary which means he did not have the authority to amend the April Delegation." The April Delegation refers to Nielsen establishing a new order of succession.

Because of this, "When Mr. McAleenan issued the November Delegation, he did so without the proper authority. Because Mr. Wolf draws his authority to serve as Acting Secretary from the November Delegation, Mr. Wolf cannot, therefore, rely upon it to serve as the Acting Secretary," the report says.

The November 2020 court ruling, the August 2020 Government Accountability Office report, and Wolf's resignation all bring up questions of whether any of his actions in office were legal. Because Judge Garaufis ruled that one of Wolf's memos was invalid because he was not serving legally, the same logic could be applied to any and all actions he took during the deployment of federal troops to Portland and other cities during summer 2020, including but not limited to the creation of the Department of Homeland Security's Protecting American Communities Task Force (PACT) and the deployment of federal agents unde the Department of Homeland Security — although President Trump deployed the troops through an executive order, Wolf allowed Homeland Security agents to be deployed.

C. The 1st, 4th, and 5th Amendment

Several lawsuits have been filed against the federal government for violations of the 1st, 4th, and 5th Amendment rights of protestors, journalists, and legal observers. Several of these lawsuits are discussed in detail in Section V: journalists and legal observers sought a temporary restraining order against the federal government because federal agents had repeatedly violated 
Tebor 13

the freedom of the press by specifically targeting journalists with gas and munitions, effectively chilling their rights in Index Papers LLC v. City of Portland. ${ }^{37}$ Oregon Attorney General Ellen Rosenblum also included 5th Amendment due process violations in her lawsuit against the federal government. ${ }^{38}$

The 4th Amendment of the Constitution of the United States of America says "the right of the people to be secure in their persons, houses, papers, and effects, against unreasonable searches and seizures, shall not be violated" unless there is probable cause, while the 5th calls for due process of the law. ${ }^{39}$

Oregon Public Broadcasting, a National Public Radio affiliate station located in Portland, Oregon, reported that days after federal law enforcement officers arrived, they used unmarked vehicles to grab protestors off Portland streets. "Personal accounts and multiple videos posted online show the officers driving up to people, detaining individuals with no explanation of why they are being arrested, and driving off," the article says. ${ }^{40}$ According to OPB, interviews show that officers were detaining people on streets that were not near federal property and that it is not clear that those who were arrested were engaged in criminal activity.

Mark Pettibone, a Portland protester, alleged that he was tossed into an unmarked van, put into a cell, and was read his Miranda rights and interviewed by two officers in the OPB article. The officers did not tell Pettibone why he was arrested, he said, and after his interview was terminated, he was released and said he did not receive any paperwork, citation or record of

\footnotetext{
${ }^{37}$ Index Newspapers LLC v. City of Portland, 3:20-cv-1035-SI, (D. Or. 2020).

${ }^{38}$ Rosenblum v. Doe, 3:20-cv-01161-MO (D. Or. 2020).

${ }^{39}$ U.S. Const. amend. IV.

${ }^{40}$ Jonathan Levinson and Conrad Wilson, Federal Law Enforcement Use Unmarked Vehicles To Grab Protesters Off Portland Streets, Oregon Public Broadcasting, July 16, 2020.
} 
his arrest. The U.S. Marshals Service provided a statement to OPB saying their officers had not arrested Pettibone. ${ }^{41}$

Oregon law permits federal forces to arrest individuals for any Class A misdemeanor, felony, or crime committed in the federal officer's presence if the federal officer has probable cause to believe the person committed the crime. The federal officer must inform the person being arrested of their authority and reason for the arrest. ${ }^{42}$

\section{Posse Comitatus Act}

The Posse Comitatus Act of 1878 was passed to prevent the federal army from assisting local law enforcement, and some argue Trump's decision to deploy federal troops in Portland falls within this area of enforcement. Posse comitatus directly translates to "power of the country." The entire act, in its most modern form, is all but one sentence: "Whoever, except in cases and under circumstances expressly authorized by the Constitution or Act of Congress, willfully uses any part of the Army or the Air Force as a posse comitatus or otherwise to execute the laws shall be fined under this title or imprisoned not more than two years, or both."

The Posse Comitatus Act does not apply "where Congress has expressly authorized use of the military to execute the law." ${ }^{43}$ Additionally, some scholars believe that several historical events where presidents used federal policing powers highlight the Act's "negligible impact on the almost unchecked scope of presidential authority as Commander in Chief."44

It seems as if the government has largely forgotten about the Posse Comitatus Act after its passing. No one has ever been convicted of the Act. ${ }^{45}$ In addition, there are multiple historical

\footnotetext{
${ }^{41} I d$.

${ }^{42}$ Or. laws $§ 133.245(2020)$.

${ }^{43}$ Charles Doyle and Jennifer K. Elsea, Cong. Rsch. Serv., R42659, The Posse Comitatus Act and Related Matters: The Use of the Military to Execute Civilian Law (2012).

${ }^{44}$ Commander Gary Felicetti and Lieutenant John Luce, The Posse Comitatus Act: Setting the Record Straight on 124 Years of Mischief and Misunderstanding before Any More Damage is Done, 175 Mil. L. Rev. 86, (2003).

${ }^{45}$ H.R. REP. NO. 97-71, pt. I (1981), reprinted in 1981 U.S.C.C.A.N. 1787.
} 
Tebor 15

examples illustrating presidential actions that would violate the Act: in 1894, President Grover Cleveland dispatched federal troops to Illinois in response to the Chicago Pullman strikes in 1894, although the governor strongly objected and before the city's major had asked for state assistance. ${ }^{46}$ At the start of the Cold War, Congress gave authorization to the President to "use all of the military services to take direct law enforcement actions in support of new authority granted to the Coast Guard in the Magnuson Act." ${ }^{47}$ In Chandler v. United States, the Posse Comitatus Act was considered "obscure and all-but-forgotten." 48

Although the governor objecting to federal involvement in the Pullman strikes could be a precedent for Trump and Portland, the Act seems to have little to no influence in the 21 st century and thus is somewhat irrelevant in determining the constitutionality of Trump's actions in Portland.

\section{E. Insurrection Act of 1807}

The largest statutory exception to the Posse Comitatus Act is the Insurrection Act of 1807, which may serve as a proper legal justification for Trump's deployment of federal troops. Despite the Posse Comitatus Act, the federal government still maintains its responsibility of protecting its citizens: Article IV, Section 4 of the U.S. Constitution permits Congress, and the Executive to protect every state in the union against invasion and domestic violence, maintaining its Republican form of government. ${ }^{49}$

At its basis, the Act allows the President to call forth the military during an insurrection or civil disturbance. ${ }^{50}$ Trump never publicly announced he was invoking the Insurrection Act when he sent federal agents to Portland, rather relying on the powers of the Department of

\footnotetext{
46 Felicetti and Luce, supra note 38.

${ }^{47}$ Id.

${ }^{48}$ Chandler v. United States, 171 F.2d 921, 936 (1st Cir. 1948).

${ }^{49}$ U.S. Const. Art. IV, § 4.

${ }^{50} 10$ U.S.C. $\S \S 251-255$.
} 
Tebor 16

Homeland Security. However, some of the statute's sections are seemingly contradictory, and there are historical examples of presidents invoking the Act without following its proper procedures. While Trump historically did not invoke the Act, it is worth discussing, as it may appear in future cases.

$\S 251$ says the Act must be invoked "upon the request of its legislature or of its governor if the legislature cannot be convened." 51 Governor Kate Brown directly requested for Trump's federal troops to leave Oregon. ${ }^{52}$

However, $\S 252$ suggests that the local authority's request is not necessary to invoke the Act: "Whenever the President considers that unlawful obstructions, combinations, or assemblages, or rebellion against the authority of the United States, make it impracticable to enforce the laws of the United States in any State by the ordinary course of judicial proceedings, he may call into Federal service such of the militia of any State, and use such of the armed forces, as he considers necessary to enforce those laws or to suppress the rebellion." ${ }^{53}$ Because this section uses broad terms, there have been historical conflicts about what events fall under this section: For instance, "President John F. Kennedy relied on this Section when he dispatched federal troops to military bases near Birmingham, Alabama to suppress periodic race riots," but only one year later, Attorney General Robert Kennedy found the section "did not apply when three civil-rights workers were killed in Neshoba County, Mississippi."${ }^{54}$

Any invocation of the Insurrection Act must be publicly announced via proclamation by the President. ${ }^{55}$ Trump did not officially declare a proclamation that he was invoking the Act, but this section of the Act is also contested: "President Herbert Hoover never issued a dispersal order

${ }^{51} 10$ U.S.C. $\S \S 251$

${ }^{52}$ Olmos, Baker and Kanno-Youngs, supra note 25.

${ }^{53} 10$ U.S.C. $\S \S 252$.

${ }^{54}$ Thaddeus Hoffmeister, The Transformative Power of Law: Article: An Insurrection Act for the Twenty-First Century, 39 Stetson L. Rev. 861, (2010).

${ }^{55} 10$ U.S.C. $\S \S 253$. 
when he used the Insurrection Act to evict the Bonus Army from Washington, District of Columbia." 56

Although it appears that Trump did not necessarily need to proclaim he was invoking the Act, he did not mention or discuss the Act when he chose to send federal agents to Portland; rather, he relied upon the powers of the Department of Homeland Security in his deployment.

\section{REACTIONS FROM POLITICAL LEADERS}

Local, state, and federal Democratic leaders were quick to denounce federal troops' presence in Portland. Portland Mayor Wheeler told Trump to 'support us' or 'stay the hell out of the way' in a press conference. ${ }^{57}$ Oregon Governor Kate Brown called Trump's actions “a blatant abuse of power," while Wheeler said they were "an attack on our democracy."58 Additionally, Portland's City Council adopted Resolution 37496 on July 22, which prohibits Portland Police Bureau's cooperation with any federal agents deployed to Portland under an executive order. ${ }^{59}$

Karin A. Power, a representative of Oregon's 41st House District, and Janelle S. Bynum, a representative of Oregon's 51st House District, both joined a lawsuit against the Department of Homeland Security alleging federal agents violated their 10th Amendment rights. ${ }^{60}$ Meanwhile, Oregon Attorney General Ellen Rosenblum took it upon herself to sue the federal government. ${ }^{61}$

On the national level, Senators Merkley and Wyden, Democrats of Oregon, introduced legislation in Washington during the summer of 2020 to stop the Trump administration from deploying federal forces in Portland after their presence seemed to have escalated violence and protests, rather than quelling them. ${ }^{62}$ Senator Elizabeth Warren wrote a scathing letter to the

\footnotetext{
${ }^{56}$ Hoffmeister, supra note 48.

${ }^{57}$ Hillary Borrud, Portland Mayor Ted Wheeler to President Donald Trump: 'support us' or 'stay the hell out of the way', The Oregonian, Aug. 30, 2020.

${ }^{58}$ Baker, Kanno-Youngs and Davey, supra note 4.

${ }^{59}$ Portland, OR., Council Res. 37496 (July 2020).

${ }^{60}$ Western States Center v. Department of Homeland Security, 3:20-cv-01175-JR (D.Or. 2020).

${ }^{61}$ Rosenblum v. Doe, 3:20-cv-01161-MO (D. Or. 2020).

${ }^{62}$ S. 4049, 116th Cong. (2020).
} 
Tebor 18

departments involved in the deployment, recommending "not to allow these personnel under your command or supervision to be used in any future domestic actions against people exercising their right to protest." ${ }^{63}$ Former U.S. Customs and Border Protection chief and former Seattle police chief Gil Kerlikowske said federal officers in Portland used 'undisciplined, unnecessary and excessive force' against protestors and legal observers. ${ }^{64}$ And former Defense Secretary Mark Esper, who Trump fired after a projected loss to former Vice President Joseph Biden in the 2020 presidential election, said he did not support invoking the Insurrection Act and said the deployment of federal troops as domestic law enforcement "should only be used as a matter of last resort and only in the most urgent and dire of situations." ${ }^{95}$

President Trump clearly disagreed with these sentiments: "We've done a great job in Portland," he said in a July 13 press conference. "Portland was totally out of control, and they went in, and I guess we have many people right now in jail. We very much quelled it, and if it starts again, we'll quell it again very easily. It's not hard to do, if you know what you're doing."66 His remarks came two days after a federal police officer in downtown Portland shot a protester in the head with an impact munition outside of the federal courthouse. The victim of the gunshot, 26-year-old Donavan La Bella, suffered brain and skull injuries and underwent intensive reconstructive surgery. ${ }^{67}$

\section{LAWSUITS}

\footnotetext{
${ }^{63}$ Letter from Elizabeth Warren, U.S. Senator, to Cabinet Secretaries, U.S. Department of Defense, Justice, Interior, and Homeland Security (July 28, 2020)

(https:/www.warren.senate.gov/imo/media/doc/2020.07.28\%20Letter\%20to\%20Cabinet\%20Secretaries\%20re\%20u $\mathrm{se} \% 20 \mathrm{of} \% 20$ force.pdf).

${ }^{64}$ Maxine Bernstein, Former U.S. Customs and Border Protection chief calls federal officers' actions in Portland: 'undisciplined, unnecessary and excessive force,' The Oregonian, Aug. 16, 2020.

${ }^{65}$ Defense Secretary Mark Esper,Defense Secretary Esper Briefing on Protests Across the U.S. (June 3, 2020) (https://www.c-span.org/video/?472733-1/defense-secretary-esper-support-invoking-insurrection-act).

${ }^{66}$ Tess Riski, President Trump Says Portland Protest Was “Totally Out of Control” but the Feds "Very Much Quelled It, ” Willamette Week, July 13, 2020.

${ }^{67}$ Ryan Nguyen and Alex Hardgrave, Police shoot Portland protester in head with impact weapon, causing severe injuries, The Oregonian, July 12, 2020.
} 
Tebor 19

\section{A. Rosenblum v. Doe}

Attorney General Ellen Rosenblum filed a lawsuit against the Department of Homeland Security, Customs and Border Protection Service, the United States Marshals Service, and the Federal Protective Service on July 17, 2020 in response to reports of federal officers snatching protestors off streets and tossing them into unmarked vans. ${ }^{68}$ She requested a temporary restraining order, as well as a preliminary injunction, "seeking to enjoin federal officers from continuing in that practice." Rosenblum alleged these seizures violated protestor's "Fourth Amendment rights of the individuals being seized, (2) they violate those persons' Fifth Amendment due process rights, (3) they violate the First Amendment rights of individuals who wish to protest but are discouraged from doing so because they fear being seized, and (4) they constitute a public nuisance. $" 69$

The temporary restraining order would have required that officers identify themselves and their agency before making an arrest and give an explanation to protestors who are seized that they are being detained or arrested, and would have created an enjoiner against arrests without probable cause.

Judge Mosman ruled against AG Rosenblum and found she lacked legal standing on July $24,2020 .^{70}$ Because she filed the suit under a rarely-used doctrine called parens patriae, Mosman said the state must have "a very particularized showing" to have standing under parens patriae. His decision also says because Rosenblum's request was to seek an injunction against future conduct, instead of seeking redress of harm that has been done to protestors, her request was "an

\footnotetext{
${ }^{68}$ Rosenblum v. Doe, 3:20-cv-01161-MO (D. Or. 2020)

${ }^{69} \mathrm{Id}$.

${ }^{70}$ Opinion and order, Rosenblum v. Doe, 3:20-cv-01161-MO (D. Or. 2020)
} 
Tebor 20

extraordinary form of relief" and that these two factors combined "render the standing inquiry an unusually high bar to clear."71

He found that Rosenblum did not provide enough evidence of an arrest that lacked probable cause — she relied upon Mark Pettibone's sworn testimony, as well as a video of what "appears to show an individual being seized without any verbal explanation from officers" that lacked context. Mosman said the alleged 1st Amendment violations were "hypothetical, with no evidence in the record to support either of them." Because Rosenblum argued that the actions of federal officers violated citizens' rights to speech and assembly, she needed to prove that illegal seizures would happen again in the future, following precedent from Lyons v. City of Los Angeles. ${ }^{72}$ Ultimately, there was no ruling on the merits of the case, but only its standing.

\section{B. Index Papers LLC v. City of Portland}

The American Civil Liberties Union, representing a number of journalists and legal observers, brought a class-action lawsuit against the City of Portland, the Portland Police Bureau, the Department of Homeland Security, and the U.S. Marshals Service in violation of their 1st and 4th Amendment rights in the U.S. District Court of Oregon, moving for a temporary restraining order and preliminary injunction. District Judge Michael H. Simon granted the temporary restraining order on July $23,2020 .^{73}$

The lawsuit includes several examples of alleged freedom of the press violations: Justin Yau, a journalist and plaintiff, alleges "he was targeted by a federal agent and had a tear-gas canister shot directly at him. At the time he was fired upon, he was taking pictures with his camera and recording with his cell phone while standing 40 feet away from protesters to make it

\footnotetext{
${ }^{71} I d$.

${ }^{72} I d$.

${ }^{73}$ Index Newspapers LLC v. City of Portland, 3:20-cv-1035-SI, (D. Or. 2020).
} 
Tebor 21

clear that he was not part of the protests." A photojournalist for the Associated Press, Noah Berger, said "the response he has seen and documented from the federal agents in Portland is markedly different from even the most explosive protests he has covered in the past.",74

Lyons v. City of Los Angeles, the same case used as precedent to reject AG Rosenblum's request, was used as precedent to grant the temporary restraining order against federal defendants in this case: "The combination of the Federal Defendants' repeated past conduct, Plaintiffs' stated intentions, and the Federal Defendants' stated intentions establish the 'real and immediate threat of repeated injury' sufficient to create standing," Judge Michael H. Simon wrote. ${ }^{75}$

Simon also said he was unsettled by images and videos of federal officers using force against nonviolent protestors. Specifically, he mentioned incidents when officers beat a Navy veteran, Chris David, with a baton when he tried to speak with federal officers outside the courthouse and the shooting of Donavan La Bella, who was peacefully standing across the street from the courthouse, was shot in the head, and suffered severe injuries. ${ }^{76}$

While the federal defendants claimed a forward-looking equitable remedy was not an appropriate solution, Simon refuted their argument, writing in his judgment that "This chilling of First Amendment rights is not adequately compensable with money damages." Simon also rejected the federal defendants' argument that “journalists have no right to stay, observe, and document when the government 'closes' public streets." 77 "Closing" of public streets includes actions such as declaring a riot, according to the suit. The decision noted that the power to close public streets is a local police function, not a federal one. Additionally, the purpose of journalists documenting when streets are closed is to report whether they were closed legally. Lastly,

\footnotetext{
${ }^{74} I d$.

75 Temporary restraining order enjoining federal defendants, Index Newspapers LLC v. City of Portland, 3:20-cv-1035-SI, (D. Or. 2020).

${ }^{76}$ Nguyen and Hardgrave, supra note 61.

${ }^{77}$ Temporary restraining order enjoining federal defendants, Index Newspapers LLC v. City of Portland, 3:20-cv-1035-SI, (D. Or. 2020).
} 
Tebor 22

defendants admitted that no journalist or legal observer has damaged any federal property or harmed any federal officer, which would be the purpose of ordering dispersal or retaliating against a journalist or legal observer.

Ultimately, the temporary restraining order prevented federal agents from arresting, threatening to arrest, or using physical force against journalists and legal observers, exempted journalists and legal observers from dispersal orders, and enjoined federal officers from seizing any photographic equipment or press passes from journalists. The temporary restraining order lasted for 14 days, but the judge extended it for another two weeks after it expired. ${ }^{78}$

Nakamura, the photojournalist for The Oregonian, said she noticed a change in federal officers' behavior after the temporary restraining order was granted.

Prior to the temporary restraining order, "when the federal officers were on the ground, there was just a blanket spraying of munitions and tear gas," Nakamura said. “There wasn't a distinguishing between who (journalists) were. Then it got kind of caught up in the courts." Afterwards, she said she noticed a shift. "I was able to cross the street with my press pass up," she said. ${ }^{79}$

\section{Western States Center, Inc. v. United States Department of Homeland Security}

This is another lawsuit filed against the Department of Homeland Security, its purpose being to "stop the federal government, its officials, and any others who have acted in concert with them, from depriving Portlanders of the right to be policed solely by those the Constitution permits, and who are accountable to Portlanders and Oregonians. Another purpose of this lawsuit

\footnotetext{
${ }^{78}$ Maxine Bernstein, Judge extends temporary restraining order against federal officers in Portland for two more weeks, The Oregonian, Aug. 6, 2020.

79 Telephone Interview with Beth Nakamura, Photojournalist, The Oregonian (Oct. 12, 2020).
} 
Tebor 23

is to vindicate the 1st Amendment rights of a church whose religious practice includes activism and protest in the face of injustice." 80

The Western States Center, a nonprofit organization which works to strengthen the organizing capacity of marginalized communities and defend democracy and democratic engagement, claimed federal defendants' overreach into local law enforcement caused the organization to suffer injury. Another plaintiff, The First Unitarian Church of Portland, Oregon, argued that federal defendants violated its 1st Amendment freedom of religion, as the church is hesitant to encourage its congregants to protest 'because defendants' unconstitutional targeting of peaceful protestors increases both the risk of bodily harm to congregants and the likelihood of the church's civil liability to congregants who are injured or traumatized in the course of abduction by federal law enforcement." ${ }^{" 81}$ U.S. District Judge Michael W. Mosman granted a preliminary injunction on a 1 st Amendment claim on October $30 .{ }^{82}$

The church also alleged a 10th Amendment violation, in that the Amendment "reserves to First Unitarian Portland, a Portland resident, the right to be policed only by Portland Police Bureau or state authorities when appropriate — and by federal authorities only to the extent authorized by valid federal law, federal regulation or the Federal Constitution." 83 The lawsuit alleged the same 10th Amendment violation for an ACLU observer. Karin A. Power, a representative of Oregon's 41st House District alleged federal officers' 10th Amendment violations "frustrated her right and ability to set state law enforcement policy applicable in Portland and throughout the state of Oregon. By infringing upon the sovereignty of the State of Oregon, defendants have diminished Representative Power's ability to establish law enforcement

\footnotetext{
${ }^{80}$ Western States Center v. Department of Homeland Security, 3:20-cv-01175-JR (D.Or. 2020).

${ }^{81} \mathrm{Id}$.

${ }^{82}$ Maxine Bernstein, Judge cites Trump's tweets as he orders restrictions on federal officers in downtown Portland protests, The Oregonian, Oct. 30, 2020.

${ }^{83} I d$.
} 
Tebor 24

policy as her constituents direct." ${ }^{84}$ Janelle S. Bynum, a representative of Oregon's 51st House District, alleged the same violations.

The first claim for relief under a violation of the 10th Amendment alleges that "By conducting traditional law enforcement activities on the sidewalks and streets of Portland — as opposed to within the vicinity, or on the premises, of government property - defendants have encroached upon powers explicitly reserved to the State of Oregon, and to Oregon's citizens, pursuant to the Tenth Amendment. Defendants conducted such law enforcement activities under color of federal law." ${ }^{\circledR 5}$ However, Mosman rejected the 10th Amendment separation of powers violation claim.

Interestingly, Mosman discussed several tweets the plaintiffs had submitted from President Donald Trump's account: "I think they satisfy the requirement of a substantial risk of future harm," Mosman said, ruling from the bench. ${ }^{86}$ He said the record "suggests evidence of potential retaliation by federal officers against protesters based on their speech." ${ }^{\prime 7}$

Less than a day before the 2020 presidential election Mosman issued restrictions against federal agents after the injunction, preventing them from controlling protest crowds beyond one block in each direction around the courthouse in downtown Portland. ${ }^{88}$ "Concerning the First Amendment claim, Judge Mosman found that former President Trump's and then-Acting Secretary Chad Wolf's public statements were sufficient to 'satisfy the requirement of a substantial risk of future harm' and specifically evinced a retaliatory motive," however, the

${ }^{84} I d$.

${ }^{85} I d$.

${ }^{86}$ Bernstein, supra note 76.

${ }^{87} I d$.

${ }^{88}$ Maxine Bernstein, Judge restricts federal officers' crowd control to 9 square blocks around U.S. courthouse in downtown Portland, The Oregonian, Nov. 2, 2020. 
Tebor 25

November 2020 injunction was vacated by Mosman about a week later because protest activity surrounding the U.S. Courthouse had ceased. ${ }^{89}$

\section{Portland and Oakland v. Barr}

In October 2020, the cities of Portland and Oakland sued U.S. Attorney General William Barr, the U.S. Department of Justice, Acting Secretary of Homeland Security Chad F. Wolf, and the U.S. Department of Homeland Security for "the unlawful and unconstitutional overreach of federal law enforcement in response to and in anticipation of civil protests in progressive United States cities. $" 90$ The lawsuit alleges the government's policies allowing federal agents to protect federal property in cities is simply a "guise" for unbounded jurisdiction of federal law enforcement.

The suit cites non-public memos from the Department of Homeland Security that say federal agents are authorized to engage in surveillance activities to protect any public monument, memorial, or statue — not just federal ones. ${ }^{91}$ It also alleges that federal defendants have engaged in unauthorized activity under the provision of Homeland Security Act of 2002 that allowed the troops to be deployed: this includes "surveilling the text messages of protesters and building a fence that blocks the right-of-way on City property and refusing to remove it upon request of City officials." 92

Ultimately, the suit alleges that federal defendants are unlawfully expanding and misconstruing the provision of Homeland Security Act of $2002 .{ }^{93}$ It offers several examples of this: the Department of Homeland Security erected a fence and barriers around the Hatfield Federal Courthouse without Portland's permission. The fence is in a city-controlled street, not

\footnotetext{
${ }^{89}$ Western States Center v. Department of Homeland Security, 3:20-cv-01175-JR (D.Or. 2020).

${ }^{90}$ Portland and Oakland v Barr, 3:20-cv-07184 (N.D. Cal. 2020).

${ }^{91} I d$.

${ }^{92} I d$.

${ }^{93} I d$.
} 
Tebor 26

federal property, and blocks a bike lane and vehicular traffic in one lane. The federal government needed to obtain a permit from the Portland Bureau of Transportation under Portland City Code Chapter 17.24, but did not. ${ }^{94}$

This lawsuit also contains allegations that the federal government illegally deputized local law enforcement, "commandeering control of local law enforcement officers in direct contravention of the City's express revocation of consent, and for unknown or pretextual ends," again violating the 10th Amendment. ${ }^{95}$ This does not directly concern Trump's deployment of federal troops, however, it is worth noting that the two issues are very similar and deal in federal law enforcement overreach.

This lawsuit does not yet have an outcome, as it is still being argued in the courts.

\section{LEGAL ANALYSIS AND CONCLUSIONS}

President Donald Trump legally deployed federal troops to Portland, Oregon during the summer of 2020. The federal troops' actions, once in Portland, were not legal. Trump acted legally in signing Executive Order 13933, which was based on 40 U.S. Code $§ 1315$ : Law enforcement authority of Secretary of Homeland Security for protection of public property. Federal troops are allowed to come into municipalities and defend federal property. It does not appear that Trump tried to invoke the Insurrection Act of 1807, and the Posse Comitatus Act is largely outdated, forgotten, and useless, seeing how no one has been charged under the Act.

There is one aspect of Trump's deployment of troops that has questionable legality: the fact that local and state leaders denounced federal agents' presence. Under the Insurrection Act, the president does not need the approval of state and local leaders, but Trump did not invoke the

\footnotetext{
${ }^{94}$ Portland, OR., City Code ch. 17.24 (2020).

${ }^{95}$ Portland and Oakland v Barr, 3:20-cv-07184 (N.D. Cal. 2020).
} 
Act. However, Section 3(b) of Trump's executive order says that the Attorney General "shall, as appropriate and consistent with applicable law, work with State and local law enforcement authorities and Federal agencies to ensure the Federal Government appropriately provides information and assistance to State and local law enforcement authorities," which blatantly contradicts Governor Kate Brown and Mayor Ted Wheeler's calls for the federal agents to leave Portland. However, because the language of the order is someone vague and reads "shall, as appropriate and consistent with applicable law," one could interpret this section as a suggestion rather than a requirement, leaving its legality in question.

Once Department of Homeland Security agents arrived in Portland, they began to engage in illegal and unconstitutional behavior. While not illegal, the Department of Homeland Security's troops were not properly trained for riot control or mass demonstrations. This is particularly concerning, considering federal troops violated the 1st, 4th, and 10th Amendments of protestors, legal observers, and journalists.

Federal agents violated the 1st Amendment rights of journalists and legal observers, as evidenced by the opinion in Index Papers LLC v. City of Portland, which led to a temporary restraining order and preliminary injunction against federal defendants. This temporary restraining order was extended after the original ruling, suggesting that it was necessary to continue protecting the 1st Amendment rights of journalists and legal observers.

Secondly, federal agents violated the 4th Amendment rights of protestors who were arrested without probable cause. Although Attorney General Ellen Rosenblum's lawsuit alleging federal agents violated protestors' 4th Amendment rights failed, she was not successful because of the extremely high bar she set for herself in filing the suit under parens patriae and seeking an injunction against future conduct, instead of seeking redress of harm that has been done to 
Tebor 28

protestors - the ruling was on standing, not merit. Mark Pettibone's testimony that he was snatched by federal officers into unmarked vans and arrested, along with a video showing the same behavior by federal officers in another circumstance, are clear violations of the 4th Amendment, especially since these seizures were not on or near federal property.

Finally, while Trump's deployment of federal officers did not violate the principles of federalism and the 10th Amendment because of their purpose to protect federal property, federal agents violated the 10th Amendment with their actions once they had been deployed. The fence surrounding the Mark O. Hatfield Federal Courthouse is the most blatant violation: federal officers refused to follow local law in erecting the fence and erected it on non-federal property. Federal agents also incriminated themselves in Index Papers LLC v. City of Portland, when they tried to argue that "journalists have no right to stay, observe, and document when the government 'closes' public streets." The federal government has no ability to close public streets; that is the duty of local law enforcement. Even the basic encroachment of federal powers into domestic law enforcement powers is a blatant violation of the principles federalism — despite the fact that the federal government allegedly deployed troops to protect federal property, which does not violate federalism, Trump's rhetoric in his Tweets suggest they were deployed to take over the duties of local law enforcement. ${ }^{96}$

Portland and Oakland v. Barr cites non-public memos from the Department of Homeland Security declaring that federal agents are authorized to engage in surveillance activities to protect any public property, not only federal property. This is in direct violation of Trump's executive order and 40 U.S. Code $§ 1315$.

\footnotetext{
96 Trump, supra note 9.
} 
Tebor 29

Although Donald Trump lost the 2020 presidential election to Joe Biden, the importance of federalism and protestor's rights is ingrained in the United States Constitution. Biden has already passed 37 executive orders in the first four months of his presidency, speaking to the ever-growing executive power in the United States. If he continues to pass executive orders at this pace, he will easily surpass the highest number of executive orders passed in one year out of any president in the past 25 years. Trump holds the current record for 69 executive orders in 2020, followed by 54 by W. Bush in 2001, 49 by Clinton in 1996, and 42 by Obama in $2016 .{ }^{97}$ Executive power continues to expand over time and Trump's deployment of federal troops can be a case study in increasing trends of executive overreach.

Ultimately, Trump was allowed to send federal agents to Portland to protect federal property and did so legally via the powers of the Department of Homeland Security and executive order. Trump deployed the troops to defend federal property, but both his rhetoric surrounding the deployment of agents and their actions have proven their purpose is to take over the duties of local law enforcement. The illegal actions of federal troops once they arrived in Portland have resulted in a disturbing, unconstitutional chilling of protestor's, journalist's, legal observer's, and Portlander's rights.

97 Executive Order Disposition Tables, 60-86 Fed. Reg. 309-17895 (Jan. 3, 1995 - Apr. 4, 2021). 
Tebor 30

\section{References}

$\S 1315$. Law enforcement authority of Secretary of Homeland Security for protection of public property, 40 USCS $\S 1315$ (Current through Public Law 116-158, approved August 14, 2020.).

10 U.S.C. $\S \S 251-255$.

Alan N. Greenspan *, NOTE: The Constitutional Exercise of the Federal Police Power: A Functional approach to Federalism., 41 Vand. L. Rev. 1019, (OCTOBER, 1988). 
Tebor 31

Alfred C. Aman, Jr. +, ARTICLE: ADMINISTRATIVE LAW IN A GLOBAL ERA: PROGRESS, DEREGULATORY CHANGE, AND THE RISE OF THE ADMINISTRATIVE PRESIDENCY., 73 Cornell L. Rev. 1101, (September, 1988).

Associated Press, Portland mayor demands Trump remove federal agents from city, The Guardian, July 19, 2020.

Briefing memorandum from the U.S. Department of Homeland Security to the acting secretary/senior official performing the duties of deputy secretary (July 16, 2020) (on file with The New York Times).

Bryon Tau, The Portland Protests, Trump Administration and Federal Authority, The Wall Street Journal, July 20, 2020.

Buchanan v. Trump, 1:20-cv-01542 ( D.D.C. 2020).

Chandler v. United States, 171 F.2d 921, 936 (1st Cir. 1948).

Charles Doyle and Jennifer K. Elsea, Cong. Rsch. Serv., R42659, The Posse Comitatus Act and Related Matters: The Use of the Military to Execute Civilian Law (2012).

Commander Gary Felicetti and Lieutenant John Luce, The Posse Comitatus Act: Setting the Record Straight on 124 Years of Mischief and Misunderstanding before Any More Damage is Done, 175 Mil. L. Rev. 86, (2003).

David G. Savage, Legal analysis: Is Trump stretching the law to deploy federal police power in cities?, L.A. Times, July 22, 2020.

Defense Secretary Mark Esper,Defense Secretary Esper Briefing on Protests Across the U.S. (June 3, 2020) (https://www.c-span.org/video/?472733-1/defense-secretary-esper-support-invoking-insurrect ion-act). 
Tebor 32

Donald Trump (@realDonaldTrump),TWITTER (Jul.30, 2020,6:20 AM), https://twitter.com/realDonaldTrump/status/1288826742539464707.

Ed Pilkington, 'These are his people': inside the elite border patrol unit Trump sent to Portland, The Guardian, July 27, 2020.

Emily Badger, How Trump's Use of Federal Forces in Cities Differs From Past Presidents, The New York Times, July 23, 2020.

Executive Order Disposition Tables, 60-86 Fed. Reg. 309-17895 (Jan. 3, 1995 - Apr. 4, 2021).

Exec. Order No. 13,933, 85 Fed. Reg. 40,081, (July 2, 2020).

Gabriella Borter, Court documents reveal secretive federal unit deployed for 'Operation Diligent Valor' in Oregon, Reuters, July 22, 2020.

H.R. REP. NO. 97-71, pt. I (1981), reprinted in 1981 U.S.C.C.A.N. 1787.

Hillary Borrud, Portland Mayor Ted Wheeler to President Donald Trump: 'support us'or 'stay the hell out of the way', The Oregonian, Aug. 30, 2020.

Index Newspapers LLC v. City of Portland, 3:20-cv-1035-SI, (D. Or. 2020).

Interview by James S. Young with Willliam P. Barr, Attorney General, United States, in Charlottesville, Va. (Apr. 5, 2001).

Jonathan Levinson, Conrad Wilson, and Ryan Hass, 50 days of protest in Portland. A violent police response. This is how we got here, Oregon Public Broadcasting, July 29, 2020.

Jonathan Levinson and Conrad Wilson, Federal Law Enforcement Use Unmarked Vehicles To Grab Protesters Off Portland Streets, Oregon Public Broadcasting, July 16, 2020.

Letter from Elizabeth Warren, U.S. Senator, to Cabinet Secretaries, U.S. Department of Defense, Justice, Interior, and Homeland Security (July 28, 2020) 
Tebor 33

(https://www.warren.senate.gov/imo/media/doc/2020.07.28\%20Letter\%20to\%20Cabinet\%20 Secretaries $\% 20$ re\%20use \%20of\%20force.pdf).

Kevin Adams, Can President Trump legally send troops to the border? It's complicated.; Critics argue the move would violate the 1878 Posse Comitatus Act. One problem: There is no 1878 Posse Comitatus Act., Washington Post Blogs , April 17, 2018 Tuesday.

Martín Jonathan Batalla Vidal v. Chad Wolf, 1:16-cv-04756-NGG-VMS, (D. NY. 2020).

Maxine Bernstein, Former U.S. Customs and Border Protection chief calls federal officers' actions in Portland: 'undisciplined, unnecessary and excessive force,' The Oregonian, Aug. $16,2020$.

Maxine Bernstein, Judge cites Trump's tweets as he orders restrictions on federal officers in downtown Portland protests, The Oregonian, Oct. 30, 2020.

Maxine Bernstein, Judge restricts federal officers' crowd control to 9 square blocks around U.S. courthouse in downtown Portland, The Oregonian, Nov. 2, 2020.

Maxine Bernstein, Judge extends temporary restraining order against federal officers in Portland for two more weeks, The Oregonian, Aug. 6, 2020.

Peter Baker, Zolan Kanno-Youngs and Monica Davey, Trump Threatens to Send Federal Law Enforcement Forces to More Cities, The New York Times, July 24, 2020.

Portland, OR., City Code ch. 17.24 (2020).

Portland, OR., Council Res. 37496 (July 2020).

Portland and Oakland v Barr, 3:20-cv-07184 (N.D. Cal. 2020).

President Donald Trump and Attorney General William Barr, Remarks by President Trump on Operation LeGend: Combatting Violence Crime in American Cities (July 22, 2020) 
Tebor 34

(https://www.whitehouse.gov/briefings-statements/remarks-president-trump-operation-legend -combatting-violent-crime-american-cities/).

Press Release, U.S. Department of Homeland Security, DHS Announces New Task Force to Protect American Monuments, Memorials, and Statutes (July 1, 2020), https://www.dhs.gov/news/2020/07/01/dhs-announces-new-task-force-protect-american-mon uments-memorials-and-statues.

Press Release, U.S. Department of Justice, Attorney General William P. Barr Announces Launch of Operation Legend, (July 8, 2020), https://www.justice.gov/opa/pr/attorney-general-william-p-barr-announces-launch-operationlegend.

Rosenblum v. Doe, 3:20-cv-01161-MO (D. Or. 2020).

Ryan Nguyen and Alex Hardgrave, Police shoot Portland protester in head with impact weapon, causing severe injuries, The Oregonian, July 12, 2020.

S. 4049, 116th Cong. (2020).

Sergio Olmos, Mike Baker and Zolan Kanno-Youngs, Federal Agents Unleash Militarized Crackdown on Portland, The New York Times, July 17, 2020.

Shawna Mizelle, READ: Acting Homeland Security Secretary Chad Wolf's resignation letter, CNN, Jan. 11, 2021.

Steve Vladeck, Are the Trump administration's actions in Portland legal? Are they constitutional?, The Washington Post, July 25, 2020.

Telephone Interview with Beth Nakamura, Photojournalist, The Oregonian (Oct. 12, 2020). Tess Riski, President Trump Says Portland Protest Was “Totally Out of Control” but the Feds “Very Much Quelled It,” Willamette Week, July 13, 2020. 
Tebor 35

Thaddeus Hoffmeister, The Transformative Power of Law: Article: An Insurrection Act for the Twenty-First Century, 39 Stetson L. Rev. 861, (2010).

The New York Times, What We Know About the Death of George Floyd in Minneapolis, The New York Times, October 23, 2020.

U.S. Const. amend. IV.

U.S. Const. amend. X.

U.S. Const. Art. IV, § 4.

U.S. Department of Homeland Security, 2020 State of the Homeland, YouTube (Sept. 9, 2020), https://www.youtube.com/watch?v=o2o-NsymK7E\&feature=emb_title.

U.S. Government Accountability Office, B-331650, Legality of Service of Acting Secretary of Homeland Security and Service of Senior Official Performing the Duties of Deputy Secretary of Homeland Security, Aug. 14, 2020.

Western States Center v. Department of Homeland Security, 3:20-cv-01175-JR (D.Or. 2020).

Wickard v. Filburn, 317 U.S. 111 (1942). 